Images in...

\title{
Primary hydatid cyst in the temporal region
}

\author{
Georgios Tsavdaris, ${ }^{1}$ loannis Konstantinidis, ${ }^{1}$ Claus Bo Svendsen, ${ }^{2}$ Caroline Ewertsen ${ }^{3}$
}

${ }^{1}$ Surgical Clinic ‘Bodosakei’, Memorial General Prefectural Hospital, Pefka, Greece

${ }^{2}$ Department of Bacteriology, Mycology and Parasitology, Statens Serum Institut, Copenhagen, Denmark

${ }^{3}$ Department of Radiology, Section of Ultrasound, Rigshospitalet, Copenhagen University Hospital, Copenhagen, Denmark

Correspondence to Caroline Ewertsen, caroline.ewertsen@dadlnet.dk

\section{DESCRIPTION}

Hydatid disease is an important infestation caused by the parasite Echinococcus granulosus. The liver is the most frequently involved organ $(75 \%)$, followed by the lungs $(15 \%)$ and the remainder of the body $(10 \%) .{ }^{1}$ We present a rare case of subcutaneous hydatid cyst in the temporal region, where a small cyst had been present for the previous 50 years. The patient was an elderly woman from Greece with a gradually enlarging mass in the left temporal fossa. During preoperative preparation, the skin covering the mass spontaneously ruptured, revealing a large cyst (figure 1) and more than 20 smaller cysts. The cysts were displacing the superficial muscles of the left temporal region and eroding the bone.

The diagnosis was confirmed by H\&E staining and treatment with albendazole was started on clinical suspicion immediately after surgery. Serological tests (direct haemagglutination) were negative and the patient had no anaphylactic reaction during her stay in hospital.

Hydatid cysts located in the head and neck region are extremely rare, even in areas where echinococcal infestation is frequent. ${ }^{12}$

Passage through the hepatic sinusoids and dissemination through the lymphatic channels of the intestine are possible routes for cases with primary hydatidosis in uncommon sites. ${ }^{1}$

Medical imaging such as CT or ultrasonography are important tools in diagnosing infestation caused by $E$ granulosus.

Hydatidosis should be considered in the differential diagnosis of superficial subcutaneous cystic lesions.

\section{Competing interests None.}

Patient consent Obtained.

\section{REFERENCES}

1. Adaletli I, Yigiter R, Selcuk D, et al. Primary hydatid cyst of the head and neck diagnosed with ultrasound and computed tomography: a report of two cases. South Med J 2005;98:830-2.

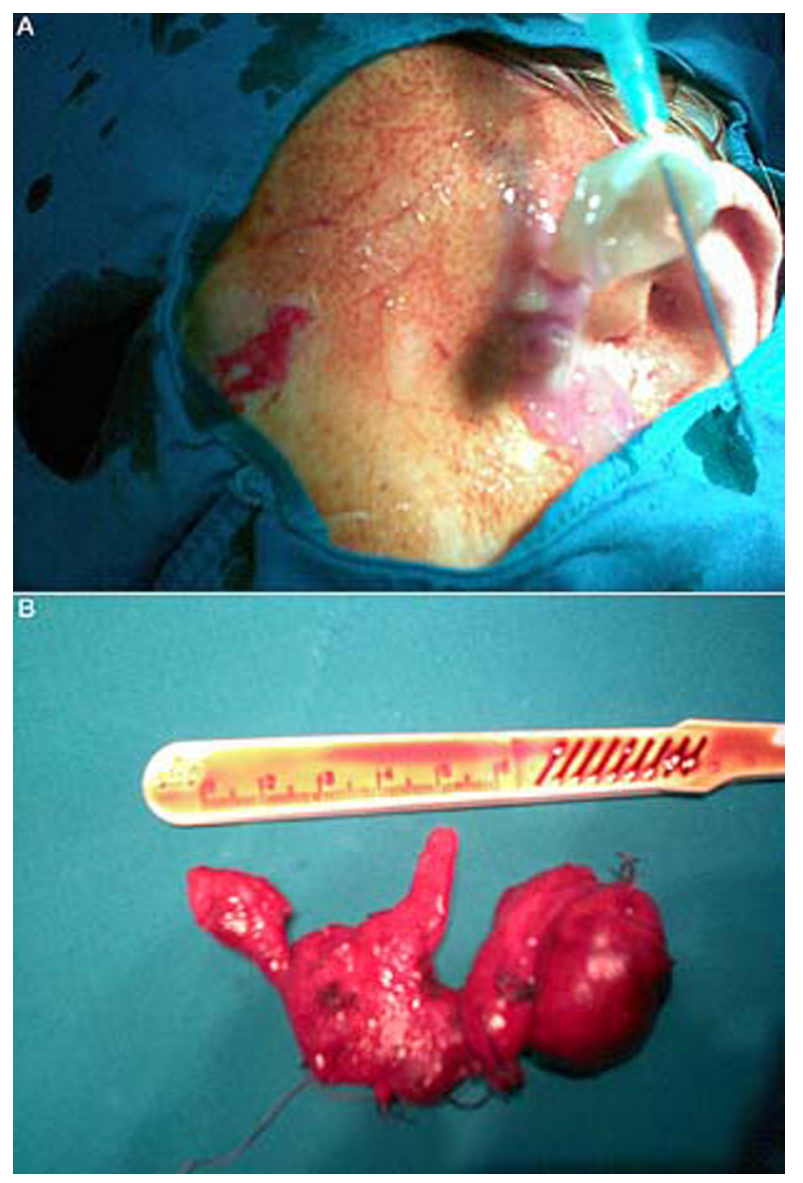

Figure 1 (A) Cysts emerging from spontaneously ruptured skin. (B) Surgically removed cysts.

2. Pasaoglu E, Damgaci L, Tokoglu F, et al. CT findings of hydatid cyst with unusual location: infratemporal fossa. Eur Radiol 1998;8:1570-2. 


\section{BMJ Case Reports}

This pdf has been created automatically from the final edited text and images.

Copyright 2010 BMJ Publishing Group. All rights reserved. For permission to reuse any of this content visit http://group.bmj.com/group/rights-licensing/permissions.

BMJ Case Report Fellows may re-use this article for personal use and teaching without any further permission.

Please cite this article as follows (you will need to access the article online to obtain the date of publication).

Tsavdaris G, Konstantinidis I, Svendsen CB, Ewertsen C. Primary hydatid cyst in the temporal region. BMJ Case Reports 2010;10.1136/bcr.11.2009.2450, date of publication

Become a Fellow of BMJ Case Reports today and you can:

- Submit as many cases as you like

Enjoy fast sympathetic peer review and rapid publication of accepted articles

Access all the published articles

Re-use any of the published material for personal use and teaching without further permission

For information on Institutional Fellowships contact consortiasales@bmjgroup.com

Visit casereports.bmj.com for more articles like this and to become a Fellow 